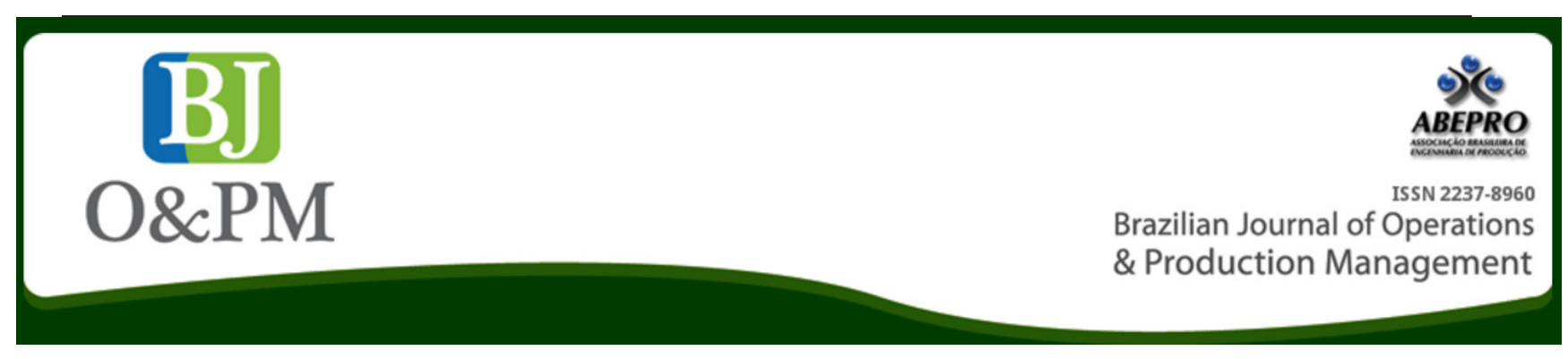

\title{
REVERSE LOGISTICS OF AGROCHEMICAL PESTICIDE PACKAGING AND THE IMPACTS TO THE ENVIRONMENT
}

\author{
Mario Fernando Mello; Rosangela Scapinia \\ ${ }^{\text {a }}$ Federal University of Technology (UTFPR) - Ponta Grossa, PR, Brazil
}

\begin{abstract}
Over time, agriculture has proven to be an important economic development factor for Brazil. The evolution and the need for productivity caused a large increase in the use of pesticides in agriculture and with it, the need to give proper treatment to packaging. With these agricultural activities in evidence, it is not possible to keep the crops without the use of pesticides. In 2000, it was created the 9,974 law as a decree Law 4,074/2002, which regulates the reverse logistics of empty containers of pesticides. This study intends to demonstrate that there are still producers who have difficulties in finding the correct destination to pesticide containers because of lack of knowledge of the law or because they acquire chemicals illegally, without a specific origin. The instruments for protecting the environment, such as licensing and environmental legislation stand out as high points, since it has the general objective of analyzing and demonstrating how reverse logistics helps minimize the impact and the possible environmental and health problems caused by the incorrect disposal of pesticide containers of and along with a group of farmers.
\end{abstract}

Keywords: Reverse Logistics; Packages; Pesticides

\section{INTRODUCTION}

Agriculture, in a country like Brazil, acts as an important development factor. However, it brings along a concern about the used packages of pesticides. The pesticide containers are hazardous to health and the environment when discarded improperly.

This study aims to demonstrate the main problems of reverse logistics caused in the environment with improperly discarded pesticide containers along with the lack of knowledge that farmers have about the proper disposal of empty pesticide containers, where to take them after using and how to clean themselves before returning them to their suppliers.

According Razzolini Filho et Berté (2009), the distribution channels are responsible for providing reception facilities for the return of empty containers, that in accordance with the principles laid down by law, while the manufacturer is responsible for the collection and the disposal of used packages.
So the aim of this paper is to analyze and demonstrate how the Reverse Logistics helps minimize the impact and possible environmental and health problems caused by the incorrect disposal of pesticide containers of a group of farmers.

\section{THEORETICAL FUNDAMENT}

This chapter contains information of authors, institutions and laws that gave theoretical support to this article.

\subsection{Business Logistics}

As Ballou said (2011), business logistics is the process of strategically managing the organization, from acquisition, handling and storage of raw materials to the final consumer. In addition to the information, flows that move the products, in order to provide differentiated services to customers, making it possible to reduce costs and thus increase profitability.

To Berkowitz et al. (2000), logistics encompasses all activities aiming to send the amount and the right products 
to the right places at the right time and at the lowest possible cost. The performance of these activities is called logistics management, which in turn corresponds to the practice of organizing the effective flow with respect to raw material costs, the product inventories in process, finished products, as well as related information from the point of origin to the point of consumption to meet the clients' requirements. From this definition, three elements can be emphasized: First, logistics handles the necessary decisions to move a product from the source of raw materials to consumption or the product flow. Second, these decisions need to be taken efficiently in costs. While it is important to reduce logistics costs, there is a limit, and this is the third point of emphasis.

According to Ballou (2011), business logistics is responsible for studying how management can, in the best way, provide the level of profitability in distribution services to customers and consumers, making planning, organizing and controlling an effective staff for handling activities and store device to facilitate the flow of producers.

Thus, the logistics business has assumed an important role in planning and controlling the flows of materials and products from the time they enter the company until their departure as finished products.

According to Leite (2009), in the 1980s with the advent of personal computers, communications systems and the digitization of information, that is, globalization has made possible to accelerate the business pace, reducing communication time and distances by virtual spaces and as a result, the logistics processes needed to be compatible with this greater operational complexity environment, high competition and volatility in the markets, making logistics something vital to corporate strategy.

With the advent of the bar codes, it has been possible to identify products and materials in various stages of their flows, digitizing the information and modifying the speed of these flows. This format will certainly mark an important advance in the activities of logistics business, contributing to its important role in the recent decades, for Leite (2009).

\subsection{Reverse Logistics}

Established by Law \# 12,305, of August 2nd, 2010, the National Policy on Solid Waste (PNRS), regulated by the decree \# 7404 of 23 December, 2010, brings the shared responsibility for the life cycle of products, reverse logistics and the sectorial agreement.

Paragraph XII of the law defines as Reverse Logistics: economic and social development tool characterized by a set of actions, procedures and means to enable the collection and the recovery of solid waste for the business sector to reuse in its cycle or other production cycles, or other environmentally disposal. (Brazil, 2010).
This definition takes into account that the flow of goods in a supply chain does not end with the final consumer or the industrial user because "[...] companies now realize that a supply chain can work the other way." (Berkowitz et al., 2000).

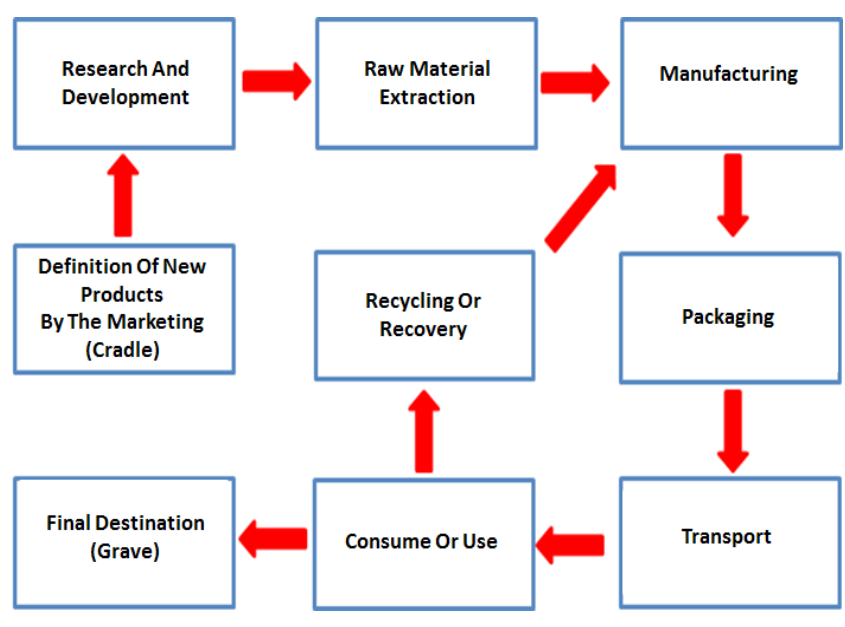

Figure 1. The life cycle of products "from cradle to grave"

Source: Compiled from Razzolini Filho et Berté (2009)

Thus, the same authors point out that reverse logistics is a process of recovery of reusable and recyclable materials, of returning and of reprocessed products from the point of consumption or use, for repair, reprocessing or disposal.

According to Buchemann (2005), when a product is launched in the market, the company directors expect it to have a long and productive life, although they know that will not sell forever since it has a life cycle. The time a product spends in each stage above is very variable, some are long in Development, others have a very great Maturity period and for others, the Decline is the most time consuming phase. In practice, it can be difficult to predict the time that each stage will last or identify with certainty the time that the product changed its 'stage', and to determine the factors that identify this change.

According to Razzolini Filho et Berté (2009), so that it becomes possible to add value to that pro-duct. After extinguished its original purpose, it is thrown away in the trash can, generating social and environmental problems that need to be addressed in the governmental sphere, an appropriate management of logistics activities is needed. It is therefore an issue, including from the standpoint of social and environmental responsibility, since society as a whole cannot be penalized for the actions of organizations that obtain profits from their activities.

The authors point out that it is necessary to recognize that reverse logistics is the factor that creates competitive advantages and assume that partial efforts are sufficient for dealing with their issues. So, to get competitive advantage from the reverse flows one must be aware that the logistics 
can provide gains in competition through differentiation of service and costs through the savings generated by the neutralization of raw materials and packaging.

In terms of competition, Razzolini Filho et Berté (2009), say it is necessary to implement reverse logistics programs that generate image by the fact that customers add value to companies that have return policy products, even if it is a requirement from the legislation for consumers' protection.

\subsection{Reverse Logistics and environment}

People are concerned about what they consume and how they consume and therefore are changing their spending habits because they realize that it is necessary to preserve the planet. This means that individuals must rethink the way they consume as well as their behavior, such as the practice of reuse of products and/or packaging by the end of its useful life, taking care with the final destination of post-consumer waste, according to Razzolini Filho et Berté (2009).

The authors note that this will only be possible with the effective participation of business and public organizations, because only with the engagement of consumers, major changes in the environment as a whole will not happen.

In this scenario, changes occur related to various products, such as models of cars, lamps, clothes, papers, among others. It is essential, therefore, the commitment of organizations to reduce environmental impacts. If consumers change, organizations will react, giving them what they want.

There is greater entrepreneurial and individual awareness in order to change the patterns of consumption. There will be benefit for all involved and the organizations that precede these requirements will gain competitive advantages.

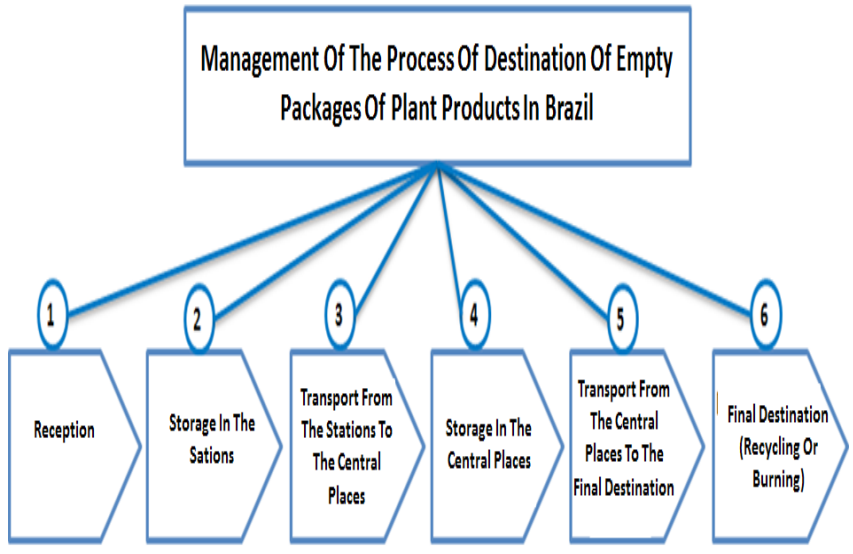

Figure 2. Destination processes of empty packages

Source: Compiled from Leite (2009)

For Dias (2011), the environmental impact is defined as the change in the environment, caused by man. Thus, there are environmental impacts of all types, from the smallest one, which substantially modifies the natural environment, and even the one that affects nature deeply, causing problems for humans such as pollution of air, water and soil.

According to the National Association of Distributors of Agricultural and Veterinary Pesticides (2000), the disposal of empty pesticide containers is a complex procedure that requires the effective participation of all those involved in the manufacture, marketing, use, licensing, inspection and monitoring activities related to the handling, transportation, storage and processing of those packages.

Considering the great diversity of packaging, pesticide formulations with different physical characteristics, chemical compositions and the requirements established by Federal Law \# 9,974 of 06/06/00 and also the decree \# 3550 of $07 / 27 / 00$, it was prepared a manual containing the minimum and necessary procedures for the safe disposal of empty pesticide containers, with the concern that any risk from handling are minimized to levels consistent with the protection of human health and the environment (ANDAV 2000).

Thus, ANDAV (2000) says that the users' responsibilities are: preparing the empty containers to return them in the receiving units; performing cleaning of washable rigid packages which can be triple or under pressure; keeping non-washable rigid packaging properly capped and without leakage.

Moreover, it is necessary for users to carry and return the empty containers, with their lids, to the nearest receiving unit, seeking guidance from the dealers on where to return within up to one year from the date of their purchases. Also, we need to keep the proof of delivery of packaging and the receipts of purchases.

ANDAV also highlights the responsibilities of dealers: providing and managing receiving units (stations) for the return of empty containers by the users/farmers; upon the sale of the product, informing users/farmers about the washing procedures, packaging, storage, transport and return of empty containers; informing the address of the nearest receiving unit of empty packaging, setting forth this information in the Invoice of Sale of the product; to be included in the prescriptions issued, the final destination of information on the packaging; in cooperation with the government, educational programs and mechanisms of control and encouraging to WASH the packages/containers (triple or under pressure) and the return of empty containers by the users. (ANDAV, 2000)

Pesticides are classified by ANVISA (2011) in four classes of danger to health. Each class is represented by a color on the label and the product label. The class I, of extremely toxic products, is represented by the red color of the label; 
Class II is represented by the color yellow and refers to highly toxic products and Class III identified by blue indicates the moderate toxic ones. The green color is responsible for representing the little toxic ones, belonging to class IV. In addition, the improper disposal of pesticide containers in rivers, plantations or even on the ground, has brought serious problems of environmental pollution such as contamination of soil, water sources and the water table, directly affecting human health. That is why it is so important to create a withdrawal system of field packaging to be recycled or incinerated, with the establishment of offices or central receiving units for their pressing and baling. The packaging can be recycled, however, should get properly washed to these locations as specified previously. After the packages are recycled they are transformed into raw materials where they can be used for manufacturing some new items.

For Gonçalves et al. (2002), the contamination of surface waters, especially rivers and streams is fast and happens immediately after irrigation. There have been serious problems arising from the application of herbicides in flood irrigation; in furrow irrigation, water carries applied, and herbicides, fertilizers, pesticides and sediment.

Water contamination can also occur more slowly through a water table, which receives fertilizers, pesticides and herbicides dissolved in the applied water. Such contamination, according to Gonçalves et al. (2002), can be aggravated if there are soluble salts in the soil, therefore, when it infiltrates in the water containing the salts applied in the field, it will even dissolve the soil salts, becoming more harmful due to environmental contamination and pesticide residues in food. It can be estimated that the next resident populations in areas of cultivation and urban dwellers are also significantly exposed to the harmful effects of these chemical agents.

When operating these systems, organizations incorporate best corporate practices in force as well as managerial and technical procedures which minimize the environmental damage possibilities, from the production to waste disposal. Thus, according to Assunção (2012), the main environmental protection instruments are: Environmental Impact Assessment (EIA); Environmental Impact Report (EIR); Environmental Control Plan (PCA); Environmental Control Report (RCA); Plan for Recovery of Degraded Areas (PRAD); Preliminary Environmental Report (RAP); Management Plan for Solid Waste (MPSW).

\subsection{Hedging instruments for the environment}

To Assunção (2012), in any public or private organization, the Environmental Law expresses the permanent search for improved environmental quality services, products and workplaces, an improvement process that enables the development of a global and comprehensive environmental management system. When operating these systems, organizations incorporate best corporate practices in force as well as managerial and technical procedures which minimize the environmental damage possibilities, from the production to waste disposal.

Thus, according to Assunção (2012), the main environmental protection instruments are: Environmental Impact Assessment (EIA); Environmental Impact Report (EIR); Environmental Control Plan (PCA); Environmental Control Report (RCA); Plan for Recovery of Degraded Areas (PRAD); Preliminary Environmental Report (RAP); Management Plan for Solid Waste (MPSW).

Still, the Law of Public Civil Action (Law 7347 of 07/24/85) protects the environmental values, discipline public civil actions for damages caused to the environment, consumers and the heritage of artistic, aesthetic, historical, tourist and landscape production.

Also in 1988, the Federal Constitution of Brazil dedicated directional standards of environmental issues, establishing the conservation guidelines and protection of natural resources and defining the environment as a common use of human society, so much so that in Article 225 of the Federal Constitution Brazilian of 1988 says: "Everyone has the right to an ecologically balanced environment and of common use and essential to a healthy quality of life, imposing both the Government and the community the duty to defend it and preserve it for the present and future generations."

Also, Rio-92 Summit - United Nations Conference on Environment and Development- reinforcement the worldwide concern with the environmental issue, reinforcing principles and rules to combat environmental degradation in the document entitled Agenda 21, which consolidates the policy of sustainable development.

Still, Law № 7802 from July 11th, 1989, deals with the research, experimentation, production, packaging and labeling, transportation, storage, marketing, commercial advertising, use, import, export, waste disposal and packaging, registration, classification, control, inspection and surveil-lance of pesticides, their components and the like, as well as other measures.

This law establishes as pesticides and related products and agents of physical, chemical or biological, intended for use in the production sector, storage and processing of agricultural products, in the pastures, in the protection of forests, native or deployed, and other ecosystems and urban, water and industrial environments and intended to change the composition of flora and fauna in order to preserve them from harmful action of organisms. Also it highlights in its article 5: § 2: pesticide users, their components and related should make the return of empty containers of products to the stores where they were purchased in accordance with 
the instructions provided in the respective package inserts within up to one year from the date of purchase, or longer period, if authorized by the registering agency, and may be mediated by the return posts or collection centers as long as authorized and supervised by the competent body.

\subsubsection{Packages}

Many physical products that come to the market need to be packaged and labeled. To Kotler (1998), the concept of packaging for the consumer with an emphasis on marketing is a set of de-sign activities and manufacturing of a container or a wrapper for a product and, therefore, one facing packing design for duty consumers to submit convenience for the consumer himself. Well-designed packaging can create value convenience for consumers and promotional value for manufacturers. In effect, they can act as 'light advertisement' for the product. Companies need to develop a packaging concept and test its functional and psychologically to ensure that it achieves the desired objectives and is consistent with public policy and social responsibility. Thus, packages can be defined as integrated materials and equipment used to carry goods and products through distribution channels, including methods of use and application of the product. It can also be an element or set of elements designed to engage, contain and protect products during their handling, transport, storage, marketing and consumption.

On the other hand, Ballou (2011) highlights other current strategic logistics functions for packaging: it facilitates storage and handling; promotes better use of transportation equipment; provides protection to products; promotes the sale of products; changes the product density; facilitates the use of products; provides reuse value to customers. It is the packaging that must be handled and the product itself is of secondary concern. It is the packaging that has shape, volume and weight while the product inside cannot have the same characteristics.

\subsection{Environmental management and social responsibility}

The new global context urges companies to adopt more sustainable management models. In this sense, corporate social responsibility is an increasing common alternative to put corporate sustainability into practice.

Concerns about the environment are assuming increasing proportions in view of the visible effects of imbalance caused by man in nature. As a result, companies are somehow managing to give answers to many questions of society.

According to Dias (2011), there are many definitions of Corporate Social Responsibility (CSR) or Corporate Social Responsibility (CSR), and it is difficult to establish a consensus on which one should prevail. In practice, the concept of
CSR is: promote business behavior that integrates social and environmental elements which are not necessarily contained in the legislation but meet the expectations of society from the company.

On the other hand, the donations the company occasionally provides are not CSR actions, but are configured as philanthropy. When it comes to social responsibility, Toldo (2002) points out that strategies are designed in order to guide the company actions in accordance with social needs. In this case the company guarantees profit, customer satisfaction and the well-being of society.

To Chiavenato (2010), Corporate Social Responsibility is a widely discussed theme propagated in the business community as an important competitive strategy tool between enterprises as it refers to the level of obligations that they must take through actions that protect and improve the well-being of society as they seek to achieve their own interests.

However, Ponchirolli (2011), presents CSR as a strategic advantage that many companies are adopting, not limited only to obligations to the community, but narrowing the relationship with this medium, through socially responsible actions. Such an approach must begin within the company with the construction and the practice of its policy and values that encourage their employees to act concerning to this new position.

For Alessio (2008), corporate social responsibility is the social performance of the company. It permeates all organizational levels, from strategy to operation. It seeks to give the company a more humane and altruistic character, which has major interests. By adopting this new way of thinking and acting, the organization seeks to make a contribution to society

\subsubsection{The social responsibility as a competitive advantage}

The social responsibility goes beyond the limits of the functional organizations, always starting on the inside and only then reaches the external environment. Then, according to Dias (2011), the first ethical responsibility should be directed to employees, then to suppliers and finally to customers. Social actions are converted and become part of the company values. There is also an improvement in human resource management, loyalty and motivation are strengthened due to the consequent improvement in the labor and increased productivity environment.

For Dias (2011), there are many ways in which companies can develop a more active role in society and comply with certain legal standards or even provide certain products and services. Along with the consolidation of ISO 26000, social responsibility and integration of enterprises, in a more active 
role for the development of a more just and sustainable society will be th key added values that will redefine the concept of quality in the XXI century.

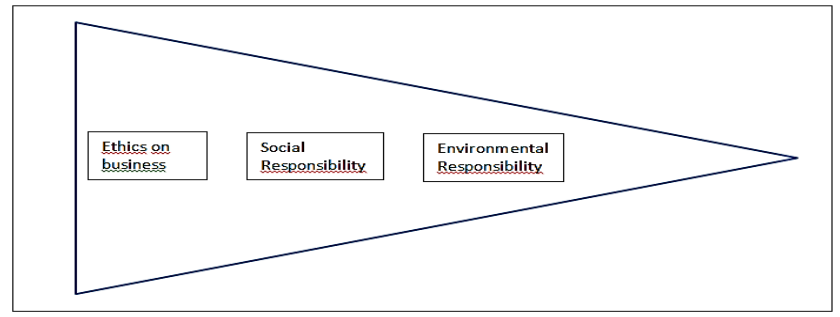

Figure 3. Dimensions of Corporate Responsibility

Source: Compiled from Razzolini Filho et Berté (2009)

The dimensions of corporate responsibility which covers business ethics, social responsibility and environmental responsibility can be shown as Figure 3 .

Companies that care about social responsibility and stand out from the others in competitiveness are concerned about the preservation of the environment and work time to adapt to cleaner production. For Melo Neto et Brennand (2004), it is not enough that companies create jobs, pay taxes, remunerate their employees and partners comply with procedures, honor commitments, produce the right products, use cleaner technology, provide convenience services, maintain a good corporate image and avoid manipulation. They need to adopt ethical management practices and contribute to build a better society.

Corporate social responsibility is a form of management that is defined by ethical and transparent relationship of the company with all the audiences with which it relates.

\section{METHODOLOGY}

This study aims to examine the reverse logistics of empty pesticide containers. It has been based on the literature and research in the field, held in April 2014, from 1st to 22nd. There were 130 surveys via e-mails personally, of which 98 of them returned.

Through these surveys, personal data and general knowledge data were collected, regarding to the return of empty pesticide containers, used in the properties of those people surveyed, located in some cities of Rio Grande do Sul state, Brazil. The objective of covering several cities was to assess the knowledge and the culture of many farmers in relation to the return of used packaging of pesticides.

Thus, this research is measured and the farmers' knowledge about the proper disposal of empty pesticide containers and the protection of the environment is analyzed in accordance with current legislation.

\section{RESULTS}

The survey results showed that females who remain in the field are only $10 \%$. This can be justified because women are more sensitive and prefer to go to town in search of other professions which do not require much physical effort or even to take care of household chores. The males who stay in agriculture are $90 \%$. This percentage is justified because men learn in their early ages to take part in the farm work watching the father figure, driving machinery and taking care of animals, actively participating in the crops and in the results so that they can keep the production processes in their properties.

When asked about the law of pesticide containers only $4 \%$ reported that they know it, but also only $8 \%$ said they fully know the law. It is a small percentage of farmers who know the legislation and it is worrying. Along with these data, it can be noticed that most farmers have information of the pesticide legislation. In this case, they will only dispose the packages improperly if there is no interest of preserving the environment and people's health.

When they were asked whether they agree with the rules of reverse logistics of empty pesticide containers, $87 \%$ of respondents said they agree and believe that the legislation has come to improve the lives of farmers, as from the existence of it, many tons of packaging stopped being burned or buried. Also with the rules being respected, it is avoided that water from light rain contaminated packaging, polluting rivers and causing the flora and fauna to die.

As for the supplier of pesticide products require, at the time of sale, the return of empty containers, $56 \%$ of respondents answered that the supplier requires the return. This is about a breach of legislation that requires that suppliers require the return of used packaging.

It was asked what kind of packages can be washed and $43 \%$ of the farmers responded that they do not know what these packages are. However, $57 \%$ of them do not know or know little about the process of package washing. This lack of knowledge might be the cause of serious damage to the environment.

In relation to the behavior of farmers in return the used packaging, $76 \%$ of respondents answered that return the used packaging to their suppliers. Yet, another concern given: $8 \%$ of farmers burn their packaging, which creates serious damage to the environment.

Whereas the pesticide containers have hazardous waste to the environment and health of those working in agricultural practices, it was asked if they have knowledge about proper disposal of the packaging. A positive fact is that only $6 \%$ said they did not know it. Although, the vast majority, $94 \%$ of them know about the proper disposal of packaging. 
Finally, it was asked if farmers have some degree of difficulty in giving the correct destination to used pesticide containers. The significant percentage of $39 \%$ of respondents told that they have mean (average) and much difficulty in giving correct destination to packaging. This item was shown that only $7 \%$ have a hard time in giving correct destination of pesticide containers, likely the farmers do not have knowledge of the law or acquire chemicals illegally without origin, making it difficult to deliver to the supplier because in return the farmer must present the purchase invoice from the supplier, it receives proof of delivery which should keep filed in their properties to show in the event of a possible inspection. So it is important to facilitate the return with new methods, so the authorities could review the current system.

\section{FINAL CONSIDERATIONS}

It was shown in this research what can be done for the legislation of empty pesticide containers to be fully met, once it is still short of the desired, because there is a strict supervision of government agencies towards manufacturers and distributors of agrochemical pesticides.

The survey of 98 farmers showed that $90 \%$ are males while $10 \%$ are females. This is due to the fact that work on the farms is more practiced by men. In terms of age, it was noticed that people who remain working in agriculture are in the range from 21 to 40 years old. Regarding to the area of the property, most have properties from 51 to 200 hectare.

Pesticides providers do not require the return of packaging, but inform in the observations, of the invoice, where they must be returned. The percentages related to farmers who know the law and return properly packaging, belong to the group that have ecological awareness, care about the environment and make the purchase at the authorized locations. But those who do not know and do not make any return, probably acquire them in the clandestine mode, so it cannot be assessed.

Thus, the overall objective was achieved through the demonstrated results and the analysis of this important issue which is the Reverse Logistics of agrochemical packaging.

Finally, because of the importance and the relevance of the topic, researches and incursions on this subject should be carried out in order to seek knowledge and assist farmers in the proper disposal of pesticide containers.

\section{REFERENCES}

Agência Nacional de Vigilância Sanitária - Anvisa (2011). Cartilha sobre Agrotóxicos. Série Trilhas do Campo. Elaborada em 19 de setembro de 2011. Disponível em:
http://www.prt21.mpt.gov.br/feceagro/AnvisaCartilha.pdf. Accessed 06 april 2014.

Alessio, R. (2008). Responsabilidade social das empresas no Brasil: reprodução de postura ou novos rumos. Porto Alegre: EDIPUCRS.

Associação Nacional dos Distribuidores de Defensivos Agrícolas e Veterinários - Andav -(2000). Destinação final de embalagens vazias de agrotóxicos. Disponível em: http:// www.andav.com.br/repositorio/36.pdf. Accessed 06 april 2014.

Assunção, J.F.M. (2012) Direito Ambiental Empresarial. Disponível em: http://www.aedmoodle.ufpa.br/mod/ forum/discuss.php?d=26507\&parent=80349. Accessed 06 april 2014.

Ballou, R. H. (2011). Logística empresarial: transporte, administração de materiais e distribuição física. São Paulo: Atlas.

Berkowitz, E. et al. (2000). Marketing. vol. 2, 6.ed. Rio de Janeiro: LTC Editora.

Brasil, Lei no 12.305, (2010) Institui a Política Nacional de Resíduos Sólidos; altera a Lei no 9.605, de 12 de fevereiro de 1998; e dá outras providências. Disponível em: http://www. planalto.gov.br/ccivil_03/_ato2007-2010/2010/lei//12305. htm. Accessed 13 march 2014.

Brasil, Lei no 7.802, (1989). Dispõe sobre a pesquisa, a experimentação, a produção, a embalagem e rotulagem, o transporte, o armazenamento, a comercialização, a propaganda comercial, a utilização, a importação, a exportação, o destino final dos resíduos e embalagens, o registro, a classificação, o controle, a inspeção e a fiscalização de agrotóxicos, seus componentes e afins, e dá outras providências. Disponível em: http://www.planalto.gov.br/ ccivil_03/leis/L7802.htm. Accessed 06 april 2014.

Brasil, Ministério do Meio Ambiente. (1999) Conselho Nacional de Meio Ambiente. Resolução CONAMA № 258 de 26 de agosto de 1999. Publicação Diário Oficial da União 02/12/1999. Brasília. Disponível em: http://www.mma.gov. br/port/conama/res/res99/res25899.html. Accessed 27 march 2014.

Buchemann, D. (2005) O ciclo de vida dos produtos. Disponível em: http://www.administradores.com.br/ artigos/administracao-e-negocios/o-ciclo-de-vida-de-umproduto/11009/. Accessed 27 march 2014.

Chiavenato, I. (2010) Comportamento organizacional. 2 ed. Rio de Janeiro: Elsevier.

Dias, R. (2011) Gestão Ambiental. Responsabilidade Social e Sustentabilidade. 2. ed. São Paulo: Atlas. 
Gonçalves, R.A.B et al. (2002) Avaliação da uniformidade de aplicação de ARS em cafeeiros irrigados por aspersã0o e gotejamento nas regiões do triângulo mineiro e Alto Parnaíba - MG. In: Simposio Brasileiro de Pesquisa em Cafeicultura Irrigada, 5, Anais, Araguari, MG.

Leite, P.R. (2009) Logística reversa: meio ambiente e competitividade. 2. ed. São Paulo: Pearson Prentice Hall.

Melo Neto, F. P. de; Brennand, J. M. (2004) Empresas socialmente responsáveis: o novo desafio da gestão moderna. Rio de Janeiro: Qualymark.

Ponchirolli, O. (2011) Ética e Responsabilidade Social empresarial. 4. reimpr. Curitiba: Juruá.

Razzolini Filho, E. et R. Berté (2009) O reverso da logística e as questões ambientais no Brasil. Curitiba: Ibpex.

Toldo, M. (2014) Responsabilidade social empresarial. Monografia apresentada ao Curso de Administração da Universidade do Extremo Sul Catarinense - UNESC em 2002. Disponível em: http://www.uniethos.org.br/_Uniethos/ Documents/Mariesa\%20Toldo.pdf. Accessed 19 de march 2014. 